JOURNAL

of Health Inequalities

\title{
Inauguration Ceremony of the Academic Year 2018/2019 in Kalisz
}

\author{
Ewa Wasielewska \\ European Observatory of Health Inequalities, the President Stanisław Wojciechowski State University of Applied Sciences \\ in Kalisz, Poland
}

ADDRESS FOR CORRESPONDENCE: Ewa Wasielewska, European Observatory of Health Inequalities, the President Stanisław Wojciechowski State University of Applied Sciences in Kalisz, 13 Kaszubska Str., 62-800 Kalisz, Poland, e-mail: e.wasielewska@pwsz.kalisz.pl

On October 15, 2018 the President Stanisław Wojciechowski State University of Applied Sciences in Kalisz (PWSZ) inaugurated the new academic year for the $20^{\text {th }}$ time. We were honoured and pleased to share this special day with distinguished guests from the world of science, academia, and diplomacy, as well as the national and local authorities. We also welcomed 1500 freshmen, including international students. The ceremony was held in the University Hall, and it was a very auspicious occasion not only due to the matriculation of first-year students but also because of the creation of a new university unit: the International Prevention Research Institute Collaborating Center.

Traditionally, the Inauguration started at the University Church of the Holy Family, where the academic community, composed of university professors, employees, and students, gathered for the Holy Mass.

The ceremonial session of the PWSZ Senate commenced with the song "Laudate Dominum" performed by the university choir.

In his Opening Speech, His Magnificence Rector, Professor Andrzej Wojtyła drew the listeners' attention to his vision of the mission of a higher education institution and presented achievements of PWSZ as well as ambitious plans for its future. He emphasised that "the very notion of the word «study» goes beyond the meaning of the word «learn», which means «to gain, acquire knowledge», and implies "analysis and in-depth exploration»". $\mathrm{He}$ added that university students and graduates "have to know how to analyse the surrounding environment and phenomena, set up observational hypotheses, choose the appropriate methodology to analyse phenomena and processes, and draw reliable, evidence-based conclusions". Hence the role of reason and science in higher education. "We are now intensifying our scientific activities, as evidenced by the creation of an interfaculty scientific unit - the European Observatory of Health Inequalities - or the resumption of activities at the Didactic Centre of Gear Wheels Research. We also undertake international scientific cooperation, as evidenced by the establishment of a collaborating centre with the International Prevention Research Institute (iPRI) Collaborating Center. It is the first scientific institution in Poland to cooperate with this Institute. Furthermore, we have also established cooperation with the International Alliance of Patient Organisation (IAPO), and Jolanta Bilińska, who is its chair, has become our lecturer. We also operate within the field of scientific publishing. The Journal of Health Inequalities, our English-language journal, has recently been awarded an Index Copernicus Value of 83.17, and I hope that next year it will enter the most prestigious list of journals: the ISI Master Journal List. In this journal, over $40 \%$ of scientific articles are published by authors from all over the world, including the USA, Europe, Asia, and Africa, also well-known ones such as Harald zur Hausen - the Nobel Prize laureate in Physiology and Medicine (2008). We are currently monitoring the citations of our journal in scientific world literature, and our careful preliminary analysis shows that the JHI may enter the ISI Master Journal List. As the Editor-in-Chief of the journal, I would like to thank Professor Witold Zatoński, the JHI Scientific Editor-inChief, for his involvement in the development of the journal, obtaining valuable scientific articles from prestigious authors from all over the world, as well as finding reviewers from abroad" - he continued. At the end of his speech, the Rector, Professor Andrzej Wojtyła, solemnly announced: "I hereby declare the 2018/2019 Academic 
Year at the President Stanisław Wojciechowski State University of Applied Sciences open!".

October 15, 2018 will be long remembered by firstyear students, who took a solemn oath and became members of the university community. The Matriculation Ceremony was performed by the Rector accompanied by Faculty Deans, and "Gaude Mater Polonia" closed it.

The Inauguration Ceremony included also a unique part: the Honorary Title "Meritorious for the President Stanisław Wojciechowski State University of Applied Sciences in Kalisz" was conferred upon Mrs Donata Szopińska-Frąszczak, the Head of the Polish Social Insurance Institution (ZUS) in Ostrów Wielkopolski, Professor Peter Boyle, the President of the International Prevention Research Institute, Lyon, France, and Professor Witold Zatoński, the Head of the European Observatory of Health Inequalities, Director of Cancer Control and Epidemiology Department, and General Director Plenipotentiary for Prevention Affairs at the Maria SkłodowskaCurie Memorial Cancer Center and Institute of Oncology in Warsaw, and the founder and the President of the Health Promotion Foundation. This title is bestowed upon individuals in recognition of their exceptional academic achievements, unquestioned authority, and moral standards.

The Inauguration Lecture was delivered by Professor Peter Boyle, an epidemiologist, the President of the iPRI, Lyon, France, a leading researcher, and a worldwide recognised authority in the field of globalisation of cancer and its prevention. The presentation was entitled "Global Public Health: Challenges and Leadership". In his lecture, Professor Boyle highlighted that tobacco, alcohol, obesity, lack of physical activity, trauma, lack of sanitation, lack of clean water, lack of electricity, and pollution are major causes of death in the world. It means, as he stressed, that many causes of death are avoidable, and "governments must do more to eradicate the disparities in health which exist. The work should not be left to charitable efforts only". He concluded, "There is a striking need for a coordinated global effort. There is a universal need for individuals, populations, and governments to engage in efforts to reduce such disparities".

The date of October 15, 2018 marks the opening of the iPRI Collaborating Center at PWSZ.

After the lecture, the cheerful "Gaudeamus Igitur" resounded in the University Hall and the Inauguration Ceremony of the Academic Year 2018/2019 at the President Stanisław Wojciechowski State University of Applied Sciences in Kalisz came to an end.

\section{DISCLOSURE}

The author reports no conflict of interest. 